7. Glaser S. Polski proces karny w zarysie wraz z prawem o ustroju sądów powszechnych. Kraków, 1934. $401 \mathrm{~s}$.

8. Papierkowski Z. Dowód poszlakowy w postępowaniu karnem, Studjum procesowo-prawne. Lublin, $1933.149 \mathrm{~s}$.

9. Nelken J. Dowód poszlakowy w procesie karnym. Warszawa, 1970. 204 s.

10. Claps A. Les indices dans le proces penal. Rochefort, 1931. $244 \mathrm{~s}$.

11. Locard E. Dochodzenie przestępstw według metod naukowych. Łódź 1937. $271 \mathrm{~s}$.

12. Waltoś S. Hofmański P. Proces karny. Zarys system. Lexis Nexis, 2016. 698 s.

13. Rosenblatt J., Makarewicz J., Ustawa o postępowaniu karnem z dnia 23 maja 1873 r. razem z odnoszącemi się do niej ustawami i rozporządzeniami objaśniona. Krakow, 1902. $602 \mathrm{~s}$.

14. Kazimierz K. Ustawa O Postępowaniu Karnem Obowiązująca W Ziemiach Rzeczypospolitej Należących Do B. Zaboru Austrjackiego: Z 23 Mja 1873 Nr 119 Dz. U.p. Warszawa : F. Hoesick, 1924. $476 \mathrm{~S}$. 1980. № 144 .

15. Brzęk W. Laboratoria kryminalistyczne Policji Państwowej // Problemy Kryminalistyki.

16. Rosenblatt J. Makarewicz J. Ustawa O Postępowaniu Karnem Z Dnia 23 Maja 1873 R. Kraków: Nakł. L. Frommera, 1911. 821 S.

17. Mitterbacher J. und Neumayer V. Erlauterungen zur Strafprozess-Ordnung vom 23. Mai 1873. Sammtdem Gesetzevom 23.Mai 1873 betreffend die Bildungder Geschwornengerichte. Graz: Verlagvon Leuschner\&Lubensky, 1874. 1014 s.

18. Ustawa o postepowaniu karnem z dnia 23 maja 1873, tudziez ustawy: o czasowem zawieszeniu Sadow Przysieglych, i o ukladaniu list Przysieglych: razem z ogloszonemi dotychczas orzeczeniami Sadu kasacyjnego, ustawami i rozporzadzeniami uzupelniajacemi i objasniajacemi, Volume 2. Bojarski, Aleksander. Kraków, 1876. 396 s.

УДК 340.113

DOI https://doi.org/10.32844/2618-1258.2019.3-1.7

ДАВИДОВ Д.о.

\title{
ЕФЕКТИВНІСТЬ ПРОЦЕСУАЛЬНО-ПРАВОВОГО РЕЖИМУ ЯК ОСНОВНА МЕТА ЙОГО ОПТИМІЗАЦІї
}

У статті розглянуто та проаналізовано ефективність правових норм як передумову гармонійного розвитку економічної, політичної та правової систем держави. Визначено поняття ефективності правових норм як систему засобів правового регулювання та способів застосування права тим суспільним відносинам, на регулювання яких воно спрямоване, у відповідності з метою, що відповідає об'єктивним умовам розвитку суспільства. Наголошено, що для забезпечення ефективності процесуально-правового режиму необхідні такі умови, як: популярність для адресатів, зрозумілість і несуперечливість правових норм, що його закріплюють, співмірністю соціальних цілей та юридичних засобів досягнення цих цілей, забезпеченість функціонування правових режимів дієвої роботою правозастосовних органів, включаючи правоохоронні та судові органи. 3'ясовано, що у процесі вдосконалення процесуально-правових режимів необхідно також визначати і закріплювати необхідний набір правових засобів, що сприяють досягненню цілей, зазначених у нормативно-правових актах, що закріплюють той чи інший галузевий режим, наприклад, у вигляді адекватних несприятливих юридичних наслідків їхнього порушення. Визначено, що з метою забезпечення ефективності процесуально-правових режимів треба створювати необхідні для цього умови: контролювати їхнє

( С ДАВИДОВ Д.О. - аспірант кафедри теорії та філософії права (Національний університет «Львівська політехніка»), начальник відділу (Військова прокуратура Центрального регіону України) 
функціонування (реалізацію, особливо застосування), виявляти недоліки їхнього правового закріплення, причини їхньої неефективності та своєчасно усувати їх, оновлювати їхню нормативну основу згідно з мінливими обставинами, приводити ïx у відповідність із суспільними потребами, усувати перешкоди на шляху їх реалізації. Зроблено висновок, що правовий режим не може і не повинен зводитися лише до встановлення обмежень і відповідальності за їхнє порушення. 3 огляду на це основне призначення процесуального режиму полягає в забезпеченні державою прав і свобод громадян, які їм гарантуються Конституцією України та, відповідно, міжнародними стандартами. Його ефективність слід розглядати власне через співвідношення між його метою, закріпленою суб'єктом правотворчості в тексті нормативно-правового акта, і реальними результатами в певних соціально-економічних та політичних умовах.

Ключові слова: право, режим, правовий режим, законодавство.

The article analyzes and analyzes the effectiveness of legal norms as a prerequisite for the harmonious development of the economic, political and legal system of the state. The notion of the effectiveness of legal norms as a system of legal regulation and methods of applying the law to those social relations, the regulation of which it is directed, in accordance with the objective that corresponds to the objective conditions of the development of society, is defined. It is emphasized that in order to ensure the effectiveness of the procedural-legal regime, the following conditions are necessary: popularity for the addressees, clarity and consistency of the established legal norms, the coherence of social goals and legal means to achieve these goals, ensuring the functioning of legal regimes by the effective work of law enforcement agencies, including law enforcement and judicial authorities. It was clarified that in improving procedural-legal regimes, it is also necessary to identify and consolidate the necessary set of legal means that contribute to the achievement of the goals specified in the regulatory acts that establish one or another sectoral regime, for example, in the form of adequate adverse legal effects of their violation. It has been determined that in order to ensure the effectiveness of procedural legal regimes, it is necessary to create the necessary conditions for this: to control their functioning (implementation, especially application), to identify the shortcomings of their legal consolidation, the causes of their ineffectiveness and timely eliminate them, update their normative basis in accordance with changing circumstances, to bring them in line with existing social needs, to eliminate the obstacles that arise on the way to their realization. It is concluded that the legal regime can not and should not be limited only to the establishment of restrictions and liability for their violation. In view of this, the main purpose of the procedural regime is to provide the state with the rights and freedoms of citizens guaranteed to them by the Constitution of Ukraine and, accordingly, international standards. Its effectiveness should be considered in fact, because of the relationship between its purpose, enshrined by the subject of lawmaking in the text of the normative legal act, and real results in certain socio-economic and political conditions.

Key words: law, regime, legal regime, legislation.

Вступ. Актуальність дослідження обраної проблеми полягає в тому, що «цільова концепція ефективності» має важливе значення під час співвідношення фактичного результату дії норм права і тих соціальних цілей, для досягнення яких дані норми були прийняті, а також дозволяє провести паралель між конкретною нормою та соціальним благом, здобутим за результатом іiі впровадження.

При цьому умови ефективності дії конкретної норми відносяться, по-перше, до самої норми; по-друге, до діяльності правозастосовних органів; по-третє, до особливостей правосвідомості і поведінки громадян, що дотримують або порушують вимоги правової норми. Поєднання всіх трьох умов забезпечує високу ефективність дії правової норми.

Аналіз останніх публікацій. Сьогодні тему ефективності правових норм досить широко досліджували вітчизняні науковці: А. Венгеров, В. Нікітинський, І. Самощенко. Певною мірою 
даної теми торкались у своїх працях П. Рабінович, О. Лейст, О. Шмалій та В. Юсупов. Водночас, незважаючи на значний інтерес науковців до теми ефективності правових норм, а також процесуально-правового режиму в цілому, існує низка питань, що потребують додаткового правового дослідження.

Постановка завдання. Метою статті є дослідити способи та методи, які дозволяють визначити ефективність процесуально-правового режиму та способи його оптимізації.

Результати дослідження. Класичної дефініцією «ефективність права» слід вважати визначення, дане В. Кудрявцевим, суть якого - у співвідношенні фактичного результату дії норм права із тими соціальними цілями, для досягнення яких дані норми були прийняті [1]. Це визначення згодом було відтворено у працях А. Венгерова, В. Нікітинського, І. Самощенко і отримало найменування «цільова концепція ефективності».

При цьому умови ефективності дії норми, за словами В. Кудрявцева, відносяться, по-перше, до самої норми; по-друге, до діяльності правозастосовних органів; по-третє, до особливостей правосвідомості і поведінки громадян, що дотримують або порушують вимоги правової норми. Поєднання усіх трьох умов забезпечує високу ефективність дії правової норми.

Більше того, ефективність органічно пов'язана з результативністю, дієвістю будь-яких заходів, правил. Право може бути високо результативним лише в тому випадку, якщо воно відповідає певним вимогам як із точки зору змісту (науково обгрунтоване, відповідає об'єктивним закономірностям розвитку, досягнутому рівню правосвідомості суспільства, внутрішньо узгоджено, своєчасно), так і форми (дохідливе стосовно мови та стилю викладу, стабільне, систематизоване, звільнене від застарілих актів та приписів, повторень, протиріч). При цьому важливо наголосити на позиції професора П. Рабіновича, який зазначає: «Ефективність правотворчості забезпечується:

1) ефективністю самого «матеріального закону» (нормативно-правового акту)»;

2) ефективністю процедурно-процесуального механізму застосування закону» [1].

Таким чином, щодо процесуально-правового режиму, то його ефективність буде визначатися умовами, що відносяться до правових норм, які їх закріплюють (якості, системності, адекватності щодо суспільних відносин); до діяльності владних суб'єктів, що їх реалізують, правозастосовних органів (органів виконавчої влади, судів, прокуратури, органів місцевого самоврядування тощо), а також до особливостей правосвідомості і поведінки суб'єктів, що правомірно реалізують свої права та інтереси в рамках певного правового режиму (процесуально-правового) або порушують його вимоги.

Прихильники так званої «корисної» концепції ефективності правових норм розуміють їхню дієвість, результативність, тобто здатність впливати на суспільні відносини в певному, корисному для суспільства напрямку. Так, О. Лейст трактує ефективність права як його здійсненність, що зумовлено загальною зрозумілістю, несуперечливістю правових норм, їхньою системністю, співмірністю соціальних цілей норм і юридичних засобів досягнення цих цілей, забезпеченістю права дієвою системою органів правосуддя та інших правоохоронних органів [2].

Для сучасних досліджень у галузі ефективності права характерні плюралістичні (інтегративні) підходи, де визначення ефективності норм законодавства включає цілий ряд аспектів:

1) цільовий (функціонально-цільовий): співвідношення між цілями норми і реальними результатами;

2) аксіологічний: ступінь відповідності норм основоположним соціальним цінностям свободи, порядку, ієрархічності, справедливості і т.д.;

3) соціальний: відповідність норм балансу соціальних інтересів, сприяння зниженню рівня деструктивної, соціально шкідливої конфліктності в даній сфері відносин, етнічної або іншої соціальної групи;

4) економічний: забезпечення економічної вигоди, економічного зростання, полегшення справедливого доступу до економічних благ і їхнього обороту;

5) психологічний: ступінь особистісного розвитку, ступінь духовної і матеріальної самореалізації особистості, які забезпечує відповідна група нормативних приписів. Психологічний аспект ефективності норм законодавства включає також ступінь формування в конкретних індивідів і їхніх груп активної громадянської позиції, внутрішньої солідарності з відповідними нормами, бажання їх добровільно дотримуватися, виконувати, використовувати або застосовувати.

Із даними аспектами ефективності норм права слід у цілому погодитися. Тим більше, що вони виділяються більшою мірою в якості основних оріснтирів правотворчої діяльності держави щодо вдосконалення норм законодавства, підвищення їхньої ефективності, а не як вимоги, яким повинна відповідати норма законодавства. 
У свою чергу, О. Шмалій ефективність адміністративно-правової норми бачить у тому, наскільки виражене в її диспозиції правило поведінки сприяє досягненню цілей правового регулювання суспільних відносин у певних соціально-економічних умовах [4]. Зазначені цілі, як виявлені в результаті нормотворчої діяльності соціальні потреби, виступають детермінантою правового впливу. Об'єктивізація мети досягається шляхом правозастосовної діяльності, в результаті якої норма права набуває конкретної форми реалізації.

I, дійсно, у цьому визначенні можна говорити про поєднання правотворчого і правозастосовного аспектів, які однаково важливі під час оцінки ефективності права (його норм, інститутів, юридичної діяльності та ін.).

В. Юсупов вважає, що проблема ефективності застосування права включає ряд питань організаційно-правового характеру: ефективність застосування норм права, ефективна організація роботи державних органів, вироблення ефективних актів і швидкість їх доведення до адресатів, ефективність виховного впливу на керовані суб'єкти. Із цією думкою можна погодитися, оскільки в ній відбивається комплексність в оцінці ефективності права [3; 5].

Таким чином, у результаті аналізу наукової літератури із проблеми оцінки ефективності правових норм (правового регулювання, правозастосовних актів, юридичної діяльності тощо) можна зробити висновки, цінні для підвищення ефективності процесуально-правового режиму.

Перше, на що слід звернути увагу: представляється не зовсім коректним, із нашої точки зору, зводити проблему ефективності права тільки до проблеми відповідності цілей, закріплених законодавцем, реально насталими результатами. По-друге, пропонуємо виділяти такі критерії комплексної оцінки ефективності права:

1) співвідношення між цілями правової норми і реально насталими результатами, тобто їі результативність;

2) відповідність норми права соціальним цінностям та інтересам (потребам).

Аналіз висловлених точок зору і власний погляд на проблему ефективності у праві дозволяє зробити висновок про те, що ефективність процесуально-правового режиму можна розглядати як співвідношення між його цілями, закріпленими суб'єктом процесуальної правотворчості в тексті нормативно-правового акта, і реально насталими результатами в певних соціально-політичних умовах.

Поряд із цим для забезпечення ефективності процесуально-правового режиму необхідні такі умови, як: популярність для адресатів, зрозумілість і несуперечливість правових норм, що його закріплюють, співмірність соціальних цілей та юридичних засобів досягнення цих цілей, забезпеченість функціонування правових режимів дієвої роботою правозастосовних органів, включаючи правоохоронні та судові органи.

У той же час основним критерієм оцінки ефективності процесуально-правових режимів $\epsilon$, звичайно ж, ступінь реалізації їх цілей.

Як відомо, цілі, які стоять перед процесуально-правовими режимами, дуже різноманітні, зумовлені впливом галузей права і об'єктів права (суб’єктів права, видів діяльності тощо), стосовно яких вони встановлюються.

Однак єдиною (комплексною) метою процесуально-правових режимів, виходячи з їхньої сутності, є оптимальне регулювання суспільних відносин, подолання перешкод, що стоять на шляху задоволення суб'єктами (правовими засобами і способами) своїх інтересів, створення сприятливого режиму для правомірних дій і несприятливого режиму для протиправних.

Мета процесуально-правового режиму охоплює змістовну сторону даного виду правового режиму - підстави, причини встановлення, від чого, у свою чергу, залежить юридичне наповнення режимного простору - термін дії, територія розповсюдження, об'єкти правового впливу, співвідношення стимулів і обмежень, юридична відповідальність за порушення режимних вимог тощо.

У цьому плані важливого значення набуває коректна постановка (формальне визначення) мети конкретних правових режимів у нормативно-правових актах, які є юридичною підставою введення, функціонування та припинення дії того чи іншого правового режиму (в тому числі і процесуально-правового).

3 одного боку, вони повинні бути соціально зумовленими: відповідати рівню соціальноекономічного та політичного розвитку суспільства, бути адекватними його правосвідомості та правовій культурі, найважливішим соціальним цінностям і ідеалам. 3 іншого боку, мета правового режиму повинна бути реальною, досяжною, точною і чіткою (однозначною).

У переважній більшості норм чинного законодавства мета однозначно і чітко формулюється законодавцем. Так, наприклад, Закон України «Про освіту» [6] містить формулювання мети, для досягнення якої був прийнятий даний нормативний акт і закріплений відповідний 
правовий режим (метою освіти є всебічний розвиток людини як особистості та найвищої цінності суспільства, розвиток іiі талантів, розумових і фізичних здібностей, виховання високих моральних якостей, формування громадян, здатних до свідомого суспільного вибору, збагачення на цій основі інтелектуального, творчого, культурного потенціалу народу, підвищення освітнього рівня народу, забезпечення народного господарства кваліфікованими фахівцями). Це дає змогу заповнити й спеціальні норми, що визначають принципи державної політики і завдання законодавства у сфері освіти. Таким чином, правовий режим освіти, закріплений вищеназваним законом, має чіткі цільові орієнтири і захищений від досить вільних трактувань його окремих положень. Тим більше, він містить спеціальну статтю, в якій не лише закріплюються цілі означеного правового режиму, але і розмежовуються його цілі і завдання. Так, відповідно до ст. 2 Закону завданням законодавства України про освіту є регулювання суспільних відносин у галузі навчання, виховання, професійної, наукової, загальнокультурної підготовки громадян України [6].

Проте відсутність у тексті нормативно-правових актів формулювань цільових орієнтирів призводять до зростаючого використання у правозастосовній практиці засобів телеологічного тлумачення [2]. Так, подібний вид роз'яснення зустрічається досить часто у практиці Конституційного Суду України і виражається в його Постановах та окремій думці його суддів.

Треба також сказати, що в ряді випадків важливого значення набуває чітке формулювання в нормативно-правових актах не тільки мети процесуально-правового режиму, але і цілей, які повинні перед ним ставитися в силу того, що вони не можуть бути досягнуті за допомогою іншого правового режиму. Даному положенню кореспондує закріплення в ст. 23 КпАП України правила, згідно з яким адміністративне стягнення є мірою відповідальності і застосовується з метою виховання особи, яка вчинила адміністративне правопорушення, в дусі додержання законів України, поваги до правил співжиття, а також запобігання вчиненню нових правопорушень як самим правопорушником, так і іншими особами [7; 11].

На наше переконання, проблема закріплення мети правового регулювання у чинному законодавстві видається більш масштабною, ніж недоліки і технічні похибки у правотворчому процесі під час формування тексту майбутнього нормативно-правового акта. Найчастіше мета правового регулювання не завжди формально визначена й з тієї причини, що відсутні стратегічні цілі та напрямки розвитку держави і права в певних сферах, що не може не позначитися і на правотворчому процесі.

У ряді випадків дана прогалина ліквідується Указами Президента України, що закріплюють Стратегії державної політики в тій чи іншій галузі [8]. Так, наприклад, Концепція національної екологічної політики України на період до 2020 року, схвалена Кабінетом Міністрів України від 17.10.2007 № 880-р [9], являє собою систему сучасних пріоритетів, цілей, принципів, основних напрямів, завдань і механізмів реалізації державної національної політики України і прийнята 3 метою ефективної системи управління у сфері охорони навколишнього природного середовища та проведення структурних реформ і модернізації технологічних процесів в умовах зростання національної економіки, призводить до збільшення рівня забруднення та зумовлена підтримкою старих, неефективних підходів до використання енергетичних і природних ресурсів [8].

Справедливо із цього приводу зауважує Ю. Тихомиров: «Згубною є недооцінка вибору цілей і підміна їx ad hoc поточними запитами. У цьому плані слід було б ретельно готувати концепції, повніше і точніше визначати преамбули і цілі закону як нормативну орієнтацію для переходу в нові стани. На жаль, безперервні поправки до чинного законодавства свідчить про втрату в них правової перспективи» [10].

Викладене з необхідністю вимагає послідовного прийняття на державному рівні спеціальних стратегій (програм, концепцій), що закріплюють сучасні пріоритети, цілі, принципи, основні напрями, завдання та механізми реалізації державної політики в різних сферах суспільного життя і своєчасне відображень даних орієнтирів у чинному законодавстві, що регламентує дані галузі.

Виключно важливо, щоб кожен нормативний акт, що закріплює основні елементи правового режиму (зокрема процесуального), містив у преамбулі або в перших статтях вказівку на ті цілі, які правотворчий орган хотів би досягти за його допомогою. Дане положення слід закріпити в Законі про нормативно-правові акти [2] в якості загальнообов'язкового правила, в іншому випадку суб'єкти права змушені будуть самі визначати цілі правового регулювання, тлумачити положення закону у вигідному для себе варіанті.

Якщо ж говорити про основну мету правових режимів, а саме про подолання перешкод, що стоять на шляху задоволення суб'єктами (правовими засобами і способами) своїх інтересів, то із цього приводу слід сказати таке. 
Коли під перешкодами розуміються природні та штучні бар'єри, що заважають досягненню цілей правового регулювання у цілому і задоволенню прав і законних інтересів громадян $\mathrm{i}$ організацій зокрема, то їхня наявність безпосередньо негативно позначається на ступені ефективності процесуально-правових режимів, знижують їі, збільшують витрати на їхню реалізацію в різних соціальних сферах.

Зауважимо, що термін «перешкода» досить часто використовується законодавцем як у міжнародних, так і внутрішньодержавних актах.

Так, наприклад, ст. 25 Конвенції Організації Об’єднаних Націй проти корупції (прийнята в м. Нью-Йорку 31.10.2003 Резолюцією 58/4 на п’ятдесят першому пленарному засіданні п’ятдесят восьмий сесії Генеральної Асамблеї ООН) містить таке розуміння перешкоджання здійсненню правосуддя: а) застосування фізичної сили, погроз або залякування чи обіцянка, пропозиція або надання неправомірної переваги з метою схиляння до давання неправдивих показань або втручання в процес давання показань або надання доказів під час провадження у зв'язку з вчиненням злочинів, визнаних такими відповідно до цієї Конвенції; б) застосування фізичної сили, погроз або залякування з метою втручання у виконання службових обов'язків посадовою особою судових або правоохоронних органів під час провадження у зв'язку з вчиненням злочинів, визнаних такими відповідно до цієї Конвенції [11].

На внутрішньодержавному рівні під перешкодами розуміються, наприклад, публічні заклики в будь-якій формі до невиконання розпоряджень або вимог працівника міліції чи посадової особи Військової служби правопорядку у Збройних Силах України у зв’язку з виконанням ним обов'язків із охорони громадського порядку або поширення завідомо неправдивих відомостей із метою провокації, непокори законній вимозі працівника міліції, якщо ці дії призвели до порушення громадського порядку (ст. 185 (7) КпАП України); невиконання посадовою особою законних вимог прокурора (ст. 185 (6)); злісна непокора законному розпорядженню або вимозі працівника транспорту, який здійснює контроль за перевезенням пасажирів, пов'язана з фізичним опором або образою, а так само з іншими протиправними діями (ст. 185 (9)) та багато інших [11].

Так, п. 2 ст. 6 Закону України «Про вибори народних депутатів України» закріплює таке положення: застосування насильства, погроз, обману, підкупу чи будь-яких інших дій, що перешкоджають вільному формуванню та вільному виявленню волі виборця, забороняється [12].

Окрім того, законодавство містить такі конструкції, як: «обставини, що перешкоджають укладенню шлюбу»; «захворювання, що перешкоджають відбуванню покарання», «чинники, що перешкоджають інноваціям» та інші, що дає підставу вважати, що законодавець під перешкодами розуміє різного роду обставини, діяння (дії і бездіяльність), що існують у різних галузях права на рівні як правотворчості, так і правозастосування, що ускладнюють реалізацію цілей правового регулювання, не дозволяють нормам права (в тому числі правовим механізмам і правовим режимам) ефективно працювати.

Тим самим оптимізація процесуально-правових режимів безпосередньо залежить від того, наскільки ці перешкоди будуть своєчасно розкриті та усунені. Іншими словами, оптимізувати процесуально-правовий режим можливо, долаючи перешкоди, що стоять перед ним.

Вважаємо, що про ефективність функціонування процесуально-правових режимів слід судити за такими параметрами:

1) відсутність (зниження) оскаржень правових актів, їхнє скасування;

2) зменшення кількості правопорушень;

3) реалізація прав, свобод і законних інтересів громадян і юридичних осіб;

4) правильне розуміння сенсу, змісту правових норм суб'єктами правових режимів і їхнє правильне використання; та інші.

Загальними критеріями ефективності процесуально-правових режимів виступають співвідношення зазначених показників із їхніми принципами і цілями.

Показники ефективності процесуально-правових режимів можуть проявлятися у визначенні ефективності діяльності органів і організацій в економічній і соціальній сфері. Оцінка ефективності управління здійснюється шляхом аналізу стану і динаміки розвитку соціальних сфер через призму:

1) очікуваної тривалості життя під час народження;

2) чисельності населення;

3) обсягу інвестицій в основний капітал (за винятком бюджетних коштів);

4) обороту продукції (послуг), виробленої малими підприємствами, в тому числі мікропідприємствами та індивідуальними підприємцями; 
5) обсягу податкових і неподаткових доходів бюджету;

6) рівня безробіття у середньому за рік;

7) реальних наявних грошових доходів населення;

8) смертності населення (без показників смертності від зовнішніх причин);

9) оцінки населенням діяльності органів виконавчої влади тощо.

Така технологія здійснюється за конкретними даними та має важливе значення. Це дає можливість зрозуміти, чому окремі органи влади можуть досягати високого рівня продуктивності та ефективності, досягати кращих результатів, а інші - ні. Дані цілі можуть базуватися на: аналізі минулого виконання; порівнянні діяльності інших аналогічних організацій та структур за певний період; затверджених виконавчих стандартах; даних приватного сектору і недержавних організацій; вивченні реальних потреб населення тощо [13; 15]. Разом із тим слід зазначити, що повноцінний правовий механізм оцінки ефективності діяльності зазначених органів, на жаль, остаточно не створено, оскільки методика оцінки ефективності діяльності органів державної влади та місцевого самоврядування фактично зводить здійснюваний нею контроль тільки до інформаційної складової частини.

Як видається, дані параметри ефективності можуть мати субсидіарний характер по відношенню до юридичних критеріїв, що дозволяє більш об'ємно охарактеризувати правовий режим діяльності державних органів.

На нашу думку, для того, щоб визнати процесуально-правовий режим ефективним, він повинен відповідати таким вимогам:

1) бути актуальним регульованим йому процесуальним відносинам, тобто своєчасно прийнятим, динамічним, здатним реагувати на мінливі соціальні реалії допомогою специфічного поєднання дозволів, заборон, зобов'язань у їхній найбільш оптимальною для тієї чи іншої ситуації комбінації; ними);

2) бути в повному обсязі забезпеченими фінансовими засобами (економічно обгрунтова-

3) мати чітку, несуперечливу нормативно-правову базу: не конкурувати (суперечити) правовим актам, що регулюють суміжні суспільні відносини;

4) бути стабільним, не наражатися на часті необгрунтовані зміни;

5) мати чіткі, однозначні, гранично прості і зрозумілі формулювання, що забезпечують їхнє однакове тлумачення і застосування на практиці;

6) не мати чисто декларативного характеру;

7) містити механізм їхньої реалізації;

8) враховувати взаємні інтереси суб'єктів правовідносин, вимоги норм моралі, моральності.

Отже, з метою забезпечення ефективності процесуально-правових режимів треба створювати необхідні для цього умови: контролювати їхнє функціонування (реалізацію, особливо застосування), виявляти недоліки їхнього правового закріплення, причини їхньої неефективності та своєчасно усувати їх, оновлювати їхню нормативну основу згідно з мінливими обставинами, приводити їх у відповідність з існуючими суспільними потребами, усувати перешкоди на шляху їхньої реалізації.

Під час вдосконалення процесуально-правових режимів необхідно також визначати і закріплювати необхідний набір правових засобів, що сприяють досягненню цілей, зазначених у нормативно-правових актах, що закріплюють той чи інший галузевий режим, наприклад, у вигляді адекватних несприятливих юридичних наслідків їхнього порушення. До того ж відповідність обраних правових засобів меті - необхідна передумова ефективності правової норми (в тому числі і процесуальної), а неправильний вибір засобів досягнення правових цілей може спотворити зміст і значення останніх.

Законодавець досить часто для позначення механізмів реалізації процесуально-правових режимів використовує такі терміни, як «засіб», «за допомогою» і т.п. у словосполученнях: «обмеження придбання, оренди господарюючими суб'єктами, що здійснюють роздрібну торгівлю продовольчими товарами за допомогою організації торговельної мережі, додаткової площі торгових об’єктів»; «право законодавчої ініціативи Уряд України здійснює за допомогою внесення законопроектів до Верховної Ради України» та ін.

Використовується в нормативній сфері і поняття «механізм». Однак у більшості випадків мова йде про одиничні правові засоби забезпечення або охорони процесуально-правових режимів. Наприклад, механізм охорони атмосферного повітря являє собою систему заходів, пов'язаних із збереженням, поліпшенням та відновленням стану атмосферного повітря, запобіганням та 
зниженням рівня його забруднення та впливу на нього хімічних сполук, фізичних та біологічних факторів (ст. 1 Закону України «Про охорону атмосферного повітря») [14].

Більш складні механізми реалізації процесуально-правових режимів встановлюються підзаконними нормативно-правовими актами. Так, соціально-економічний розвиток регіонів в Україні здійснюється на основі комплексу правових, організаційних, наукових, фінансових та інших заходів, спрямованих на досягнення сталого розвитку регіонів на основі поєднання економічних, соціальних та екологічних інтересів на загальнодержавному та регіональному рівнях, максимально ефективного використання потенціалу регіонів в інтересах їх жителів та держави у цілому (ст. 1 Закону України «Про стимулювання розвитку регіонів») [15].

Засоби і способи правового впливу в рамках процесуально-правових режимів можуть бути представлені таким чином:

1) засоби і способи загальнонормативного регулювання (загальні правила, порядок створення, реорганізації та ліквідації організацій, системи діяльності тощо); програмно-інсталяційні способи (цільові програми; тематичні плани; концепції, функціональні правила; схеми управління); легалізаційні засоби (ліцензування; акредитація; сертифікація); способи нормативно-кількісного виміру (стандарти; ціни; нормативи; ліміти; податки (збори); плата; ставки (митні збори та ін.); контрольно-облікові засоби (облік; статистична звітність; перевірки та інші форми контролю);

2) засоби і способи підтримання належного рівня діяльності та ії стимулювання (кредити; пільги; відстрочки; дотації; субсидії; трансферти; надбавки; заохочення; держзамовлення; держзакупівлі);

3) засоби і способи обмеження діяльності у встановлених законом випадках: приписи; санкції (штрафи та ін.)); позбавлення легальності (призупинення, визнання недійсними угод, дій, актів).

Висновки. Отже, аналіз нормативно-правових актів свідчить про те, що юридичні засоби і механізми необхідно встановлювати в законодавстві більш послідовно, оскільки процесуально-правовий режим як система юридичних засобів, необхідних для досягнення певної мети (або рішення задачі), повинен являти собою саме алгоритм досягнення останніх.

Разом із тим вважаємо, що правовий режим не може і не повинен зводитися лише до встановлення обмежень і відповідальності за їх порушення. 3 огляду на це основне призначення процесуального режиму полягає в забезпеченні державою прав і свобод громадян, які їм гарантуються Конституцією України та, відповідно, міжнародними стандартами. Його ефективність слід розглядати через співвідношення між його метою, закріпленою суб'єктом правотворчості в тексті нормативно-правового акта, і реально насталими результатами в певних соціально-економічних та політичних умовах.

\section{Список використаних джерел:}

1. Рабінович П.М. Ефективність юридичних норм: загальнотеоретично-поняттєвий інструментарій дослідження. Вісник Академії правових наук України. 2008. № 1(52). С. 20.

2. Лейст О.Э. Сущность права. Москва, 2002. С. 93.

3. Кіндрат П.В. Оцінка ефективності законодавства: критерії ефективності. Науковий вісник Херсонського держсавного університету. 2014. Вип. 4. Том 1. С. $19-22$.

4. Жинкин С.А. Эффективность права: антропологическое и ценностное измерение : автореф. дис. .... канд. юрид наук. Краснодар, 2009. С. 10.

5. Шмалий О.В. Правовое обеспечение эффективности исполнительной власти (теоретикометодологические аспекты) : автореф. дис. ... докт. юрид наук. Ростов н/Д., 2011. С. 24.

C. 118 .

6. Юсупов В.А. Правоприменительная деятельность органов управления. Москва, 1979.

7. Закон України «Про освіту» від 23.05.1991 № 1060-XII. URL : http://zakon2.rada.gov.ua/ laws/show/1060-12. 2009. C. 49.

8. Настасяк І.Ю. Тлумачення правових норм: навчальний посібник. Львів : ЛьвДУВС,

9. Так, Президент України Петро Порошенко затвердив «Стратегію реформ-2020». «Мета наших амбітних реформ - досягти європейських стандартів життя і підготуватися до того, щоб у двадцятому році подати заявку на членство в $C C »,-$ заявив Глава держави. URL : http://mihrda.gov.ua/index.php/novini/581-stratehiia-reform-2020-meta-reform-chlenstvo-v-yes.

10. Розпорядження Кабінету Міністрів України від 17.10.2007 № 880-р Про схвалення Концепції національної екологічної політики України на період до 2020 року. URL : http://zakon4.rada.gov.ua/laws/show/880-2007-p. 
11. Даний законопроект перебував на розгляді Верховної Ради України, проте його скасовано. Вважаємо за доцільне все ж таки прийняти даний нормативно правовий акт (Див.: Євграфова Є. Законопроект про нормативно-правові акти: парламентсько-президентська практика). URL : http://www.justinian.com.ua/article.php?id=3117.

12. Кодекс про адміністративні правопорушення.

13. Закон України Про вибори народних депутатів України від 17.11.2011 № 4061-VI. URL : http://zakon2.rada.gov.ua/laws/show/4061-17.

14. Бабінова О.О. Критерії оцінки ефективності діяльності органів місцевого самоврядування: світовий досвід та Україна. Стратегічні пріоритети. № 2(3). 2007 р. С. 77.

15. Закон України «Про охорону атмосферного повітря» від 16.10.1992 № 2707-XII. URL : http://zakon2.rada.gov.ua/laws/show/2707-12.

16. Закон України «Про стимулювання розвитку регіонів» від 08.09.2005 № 2850-IV. URL : http://zakon4.rada.gov.ua/laws/show/2850-15.

УДК 340.15

DOI https://doi.org/10.32844/2618-1258.2019.3-1.8

ДОБКІНА К.Р.

\section{ІСТОРІЯ СТАНОВЛЕННЯ ТА РОЗВИТКУ ІНСТИТУТУ УЧАСТІ В ЦИВІЛЬНОМУ СУДОЧИНСТВІ ДЕРЖАВНИХ ОРГАНІВ: ЗАГАЛЬНОТЕОРЕТИЧНИЙ АСПЕКТ}

Наукова стаття присвячена дослідженню історії становлення та розвитку інституту участі в цивільному судочинстві державних органів. 3 урахуванням комплексного аналізу визначено, що окремі риси правового захисту чужих інтересів, були притаманні українському цивільному судочинству за часів Російської імперії. Головним чином це проявлялося у діяльності спеціально створюваних органів 3 нагляду за дотриманням усіма місцевими органами влади законів щодо захисту майнових, фінансових інтересів держави.

3'ясовано, що після судової реформи 1864 року захист чужих прав отримав якісно-новий напрямок. Діяльність прокурорів у цивільному процесі була розширена деякими категоріями справ та виходила за рамки цивільних позовів, адже додатково охоплювала захист прав та законних інтересів окремих громадян. Статут цивільного судочинства відносив до такої діяльності справи щодо окремих категорій громадян: неповнолітніх, безвісно відсутніх, недієздатних осіб, а також окремі цивільні справи щодо шлюбних відносин.

Відповідно до норм Кодексу про акти громадянського стану 1918 р. органам державної влади надавалося право звертатися до суду із позовом щодо позбавлення батьківських прав, а для захисту інтересів непрацездатних громадян у суді передбачалося створення та функціонування відділів соціального забезпечення. Окрім того, житлово-санітарні інспекції, які здійснювали нагляд за житловими приміщеннями в сфері виконання санітарних правил, повинні були сприяти у правильному вирішенні справ про розселення у житлові приміщення незабезпечених груп населення.

Доведено, що цивільно-процесуальне законодавство 20-х років XX століття містило лише форми участі у цивільному процесі прокурора, водночас, форми звернення до суду інших органів державної влади, які мали б на меті відстоювати права та законні інтереси держави та окремих громадян не знайшли свого відображення у ЦПК УСРР 1924 року, хоча норми матеріального права передбачали окремі права органів державної влади по захисту прав та законних інтересів інших осіб у цивільному судочинстві.

Ключові слова: ичвільне судочинство, органи державної влади, органи прокуратури, радянське законодавство, УСРР.

() ДОБКІНА К.Р. - кандидат юридичних наук, доцент, декан юридичного факультету (Державний університет інфраструктури та технологій) 